Boiko, A., Zwolińska-Ligaj, M., Bozhenko, V., Florczak, E., \& Ovcharenko, V.

(2021). Readiness for implementing innovations in banking in advanced and

emerging economies. Journal of International Studies, 14(4), 236-250.

doi:10.14254/2071-8330.2021/14-4/16

\title{
Readiness for implementing innovations in banking in advanced and emerging economies
}

\author{
Anton Boiko \\ Department of Economic Cybernetics, Sumy State University, \\ Ukraine \\ a.boiko@uabs.sumdu.edu.ua \\ ORCID 0000-0002-1784-9364 \\ Magdalena Zwolińska-Ligaj \\ Pope John Paul II State School of Higher Education in Biała \\ Podlaska, Poland \\ m.zwolinska-ligaj@dydaktyka.pswbp.pl \\ ORCID 0000-0001-6770-7092
}

\section{Victoria Bozhenko}

Department of Economic Cybernetics, Sumy State University, Ukraine

v.bozhenko@,uabs.sumdu.edu.ua

ORCID 0000-0002-9435-0065

\section{Ewelina Florczak}

Faculty of Economics and Management, Lazarski University,

Warsaw, Poland

ewelina.florczak@gmail.com

ORCID 0000-0002-5958-7163

\section{Volodymyr Ovcharenko}

Department of Economic Cybernetics, Sumy State University,

Ukraine

v.ovcharenko@uabs.sumdu.edu.ua

ORCID 0000-0001-9058-5775

Abstract. The development of innovation requires special knowledge from various management areas, as well as technological and intellectual support from the state. The study aims to assess the country's readiness to introduce innovative banking technologies. The methodological tools used for the study include bibliographic analysis, fuzzy logic, factor analysis, and the Brown-Mayer model. 
of countries: advanced economies (Germany, France, Czech Republic, and Spain), emerging markets and developing economies (Ukraine, Poland, Turkey, Croatia, Romania). The results of bibliometric analysis obtained with VOSViewerv.1.6.10 toolkit prove that the most significant factors affecting the country's readiness to implement banking innovations are intensive economic growth, development of information and communication technologies in society, and financial strength of the banking system. The assessment results show a gradual improvement of technological and economic conditions that are necessary for the intensification of innovation processes in banking in the countries. France, Germany, Turkey, and Poland are among the leading countries with the best conditions for the development of banking innovations, while Ukraine, Croatia, and Romania have the least favorable conditions among analyzed countries. The results of this empirical study can be used to formulate a strategic plan for the development of a country's banking system.

Keywords: fuzzy logic, investment attractiveness, bank, financial services, innovation
DOI:

$10.14254 / 2071$ $8330.2021 / 14-4 / 16$

JEL Classification: C01, G21, O10

\section{INTRODUCTION}

The increased volatility in global commodity and financial markets (Przekota et al., 2019), uncertainty of the world economic outlook (Karkowska and Kravchuk, 2019; Korzeb \& Niedziółka, 2020), devaluation of the national currency, macroeconomic imbalances (Correia \& Martins, 2019; Biegun \& Karwowski, 2020), new threats related to personal data protection (Lăzăroiu et al., 2018), increase in cybercrime (Afonasova et al., 2019), and excessive riskiness and speculative nature of banking operations in systemically important banks and contribute to potential increase in credit, liquidity and operational risks due to the interconnection of financial system participants and economic entities. To mitigate these risks, central banks are prompted to strengthen the regulatory standards and macroprudential norms (Mikhaylova et al., 2019; Lăzăroiu et al., 2018). Under these conditions, the central banks and the financial institutions face two important tasks: restoring confidence of the population and economic entities in the stability and reliability of the domestic financial system and transforming approaches to banking to make them consistent with current realities and challenges of dynamic development of economic relations (Frolov \& Lavrentyeva, 2019; Hussain et al., 2020).

Currently, financial institutions actively use innovative approaches to customer service based on modern methods of analysis and processing of information, as well as information and communication technologies. Four factors promote the intensive use of information technologies in the banking sector. First, the latest technologies allow for the acceleration of many banking operations and, accordingly, make it possible to simplify and optimize both operational activities and banking in general (Wolnicki \& Piasecki, 2019; Leonov et al., 2019; Ijaz et al., 2020). Second, transformational changes in banking activities (Didenko et al., 2018), namely the reduction of departments and staff involved in customer service and communication, lead to a reduction in bank costs (Dovha and Boychenko, 2017) and the number of direct customer contacts with bank staff, thus limiting the impact of the "human" factor in relationships with customers (Naroș, 2019; Székely et al., 2020). Third, innovations provide a significant competitive advantage for a banking institution in the financial services market (Kozmenko and Vasyl'yeva, 2008; Vasylieva et al, 2014; Adeyinka et al, 2019; Karaoulanis, 2018; Liu et al, 2019), contribute to increase in its profitability (Adeyinka et al, 2019; Goncharenko and Lopa; 2020) and the capitalization level (Obidjon, 2017), etc. 
Fourth, modern technologies provide an opportunity to expand service geography and increase customer base since customers have access to many banking services without visiting a bank branch. Besides, the banking institution image regarding the use of modern information and communication technologies also contributes to the growth of the client base (Faccia et al, 2020). According to Yarovenko et al (2021), it is advisable to implement biometric technologies to reduce operating costs and to identify customers in mobile devices to improve customer service for banks remotely. Thus, banking innovation can benefit in terms of profits. It can simplify banking operations by employees, increase financial inclusion, and stimulate sustainable investments (Chigrin and Pimonenko, 2014; Bilan et al, 2020).

At the same time, it is risky for banking institutions to invest funds in innovative technologies since innovations may not bring the desired economic and image effect (Benazzouz, 2019). Besides, innovations implemented in the bank open up opportunities for its development in a long-term perspective when technological advantages are lost in the current period (Zakutniaia and Hayriyan, 2017; Lewandowska and Stopa, 2020). Moreover, implementing ICT-based innovation simplifies access to banking services but makes them technologically more complicated (Mangani et al., 2019; Alikariev and Poliakh, 2018), which can alienate customers. There is an active transition of customers to mobile platforms to access banking services. At the same time, Didenko et al (2020) are convinced that the low level of using digital financial services depends on behavioral aspects. One should mention that using the latest technologies is accompanied by the additional costs to purchase the necessary equipment, software, salary for the specialists and/or services of Hi-Tech companies, etc.

The banking service market participants providing financial services along with their main activity are becoming more popular. They include FinTech companies, mobile operators, Facebook, Google, etc. (Druhov et al., 2019).

Summarizing, we note that in current conditions, the innovative development of the banking sector of any country largely depends on the following: financial, organizational, and managerial capabilities of banks, the level of development of economic relations in the country, the skills and competencies of the population in the field of digital technologies, and the level of evolution of information and telecommunications infrastructure in the country. In this regard, the paper proposes to assess the impact of three main determinants (intensive type of economic growth, development of information and communication technologies, and the financial strength of the banking system) on the country's readiness to introduce innovations in the banking sector.

\section{LITERATURE REVIEW}

A bibliometric analysis was carried out using the VOSViewerv.1.6.10 toolkit for a more detailed study of the impact of the determinants mentioned above on the development of banking innovations in the country (Cicea, 2020). It allowed identifying the relationships between objects, clustering, and visualizing scientometric data. Thus, 1,746 scientific articles corresponding to the simultaneous inclusion of such categories as "bank" and "innovation" in the search query for 1992-2020 in journals indexed by the Scopus scientometric database were selected as the object of bibliometric analysis. The study showed that the number of publications focused on innovation in the banking sector began rapidly growing in 2010, and this trend persists. The analysis of the frequency of using keywords on this issue in scientific papers resulted in defining 4 clusters characterizing the relation with the concept of the knowledge economy (pattern 1), the development of IT in financial and economic relations (pattern 2), the development of the banking business and its components (pattern 3), and the forms and types of banking innovation (pattern 4) (Fig. 1). The bibliometric analysis has confirmed that the determinants of impact were selected correctly to determine the country's readiness to implement banking innovations. 
Moreover, international research centers engaged in studying this issue have been grouped based on their geographic location. Based on the analysis of scientific papers, the authors of which are from 147 countries, six clusters have been identified. Despite the internationalization of research, the most efficient research in this area was carried out by scientists from the USA, Great Britain, China, Canada, India, and Italy.

A detailed analysis of scientific papers characterizing the features of the development of financial and economic relations showed the dependence of the development of banking innovations on the following factors: economic conditions, the emergence of digital currencies and their use as an alternative to fiat money (Knezevic, 2018; Nikic, 2018), the digitization of various spheres of public life (Cwiklicki \& Wojnarowska, 2020; Petroye et al., 2020), the competition in the banking service market (Skvarciany et al., 2018; Aldomy et al., 2020), sufficient financial resources (Leonov et al., 2014), trust in the domestic participants of the banking system (Brychko et al., 2019, 2020), the efficiency of banks (Kasim et al., 2019; Bod'a \& Zimkova, 2019), business transparency (Vasilyeva et al., 2017).

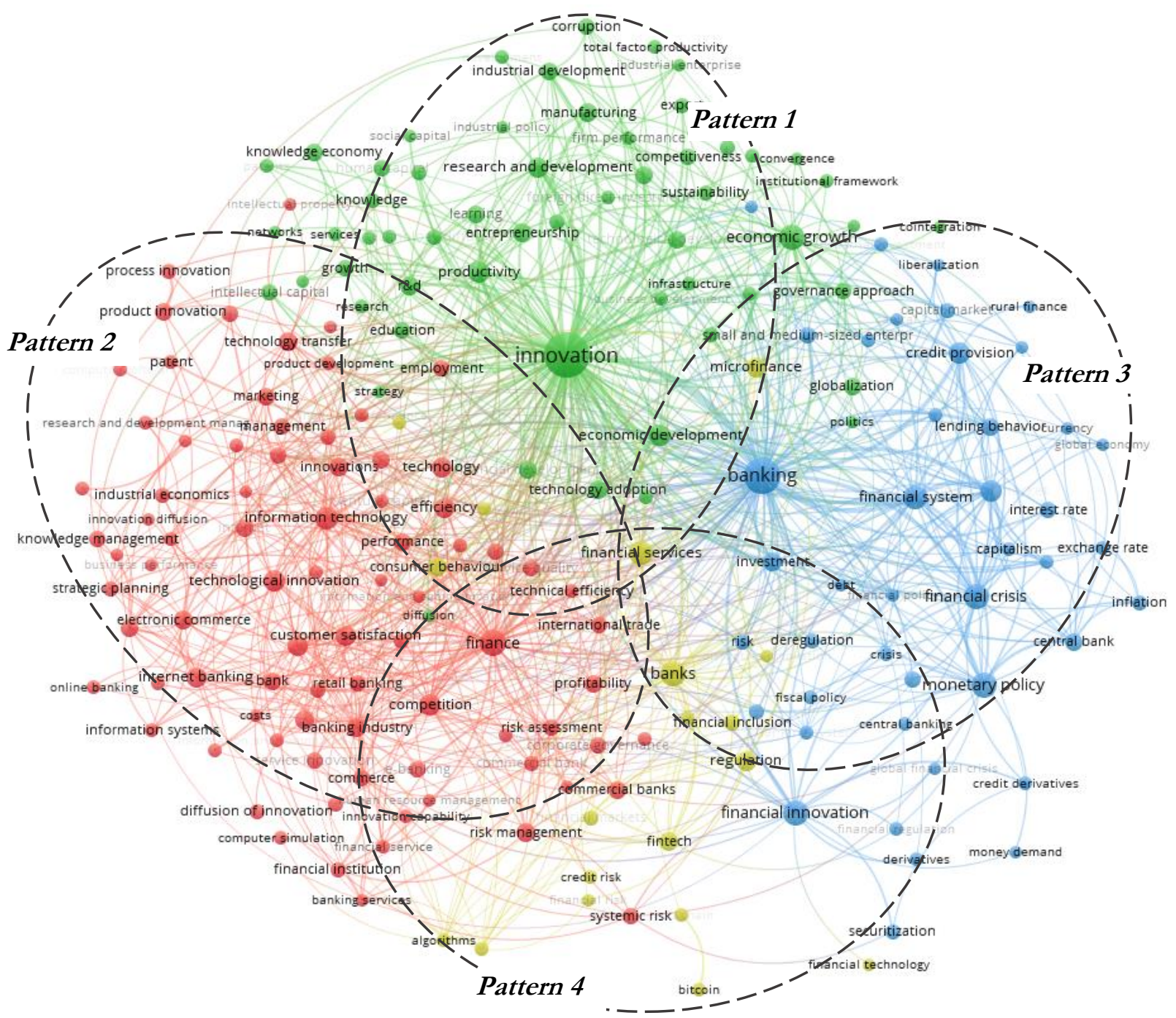

Figure 1. Results of bibliometric analysis of scientific papers on the theory of banking innovations for 1992-2020 in publications indexed by the scientometric database Scopus

(VOSViewerv.1.6.10 toolkit)

Source: Authors' calculations 
Structural modelling (Prayitno et al., 2021) and regression analysis (Vasilyeva et al., 2014b) are used to determine the correlation degree between banking development indicators. Particular attention should be given to the approach to investment or any other managerial decision, taking into account the bank's strategic development goals based on the use of bifurcation theory (Vasilyeva et al., 2019).

Despite the large number of publications dealing with the specified problems, there are no fundamental studies assessing the level of readiness to introduce banking innovations. In the scientific literature, the Harrington function is often used as an integrated indicator to assess the efficiency, financial stability and reliability of banking institutions (Kuzmenko and Koibichuk, 2018).

\section{METHODOLOGY}

This study puts forward two hypotheses:

Hypothesis 1: the readiness to implement innovative banking technologies in countries with advanced economies is higher than in emerging markets and developing economies.

Hypothesis 2: the set of significant factors influencing the readiness to introduce banking innovations differs between advanced economies, emerging markets, and developing economies.

The following methods were used in the study: abstraction (formation of hypotheses); the principal component method (determination of the most significant factors influencing the intensity of implementing banking innovations); fuzzy logic (quantitative description of the readiness to implement innovations in the banking sector); Harrington's method (assessment of the readiness) and Brown-Mayer method (forecasting).

The object of the study was advanced economies (Germany, France, Czech Republic, and Spain), emerging markets, and developing economies (Ukraine, Poland, Turkey, Croatia, Romania). The information base of the study was formed based on the annual data for 2004-2018.

Thus, a methodological approach has been developed to assess the current level and forecast the readiness of the country to implement innovative banking technologies. It is implemented as the following sequence of stages:

\section{Formation of information and statistical base of research.}

An in-depth analysis of the existing experience of introducing banking innovations in different countries and the bibliometric study confirmed the feasibility of considering such processes during the research:

- intensive type of economic growth, which involves the implementation of the provisions of the "knowledge economy" concept, namely the development of innovation, production of knowledge-intensive products, increasing intellectual capital, which together determines the pace and prospects of economic growth in the country;

- development of information and communication technologies, which determines the nature of infrastructure support for the development of economic entities, including banking institutions;

- the financial strength of the banking system, which characterizes the financial capacity to invest in innovative projects.

Thus, it is proposed to characterize the intensive type of economic growth based on the following indicators: research and development expenditure ( $\%$ of GDP) $-\mathrm{x} 1$, foreign direct investment ( $\%$ of GDP) $-\mathrm{x} 2$, net investment in nonfinancial assets (\% of GDP) $-\mathrm{x} 3$, technicians and researchers in R\&D (per million people) $-\mathrm{x} 4$, labor force with advanced education ( $\%$ of total) $-\mathrm{x} 5$. The development of information and communication technologies in the country is evaluated based on the following indicators: secure Internet servers (per 1 million people) - x6, mobile cellular subscriptions (per 100 people) $-x 7$, fixed broadband subscriptions (per 100 people) $-x 8$, ICT goods exports ( $\%$ of total goods exports) $-x 9$. The financial strength of the banking system is considered based on the non-performing loans ( $\%$ of total gross 
loans) $-\mathrm{x} 10$, bank capital to assets ratio $(\%)-\mathrm{x} 11$, return on assets $(\%)-\mathrm{x} 12$. The source of the information base of the study was the data of the World Bank, International Monetary Fund, Telecommunication Development Sector under the United Nations Development System.

To ensure the informational unidirectionality of indicators, the selected indicators are incentives since their increase results in the growth of the integral indicator.

While forming the statistical base of the study, it became necessary to find the missing or unknown values of indicators in the proper periods. The average annual growth rate coefficient $\bar{K}$ is used:

$$
\bar{K}=\sqrt[n-1]{\frac{y_{n}}{y_{1}}}
$$

where $y_{n}$ - the final level of the row;

$y_{1}$ - the initial level of the row;

$n$ - number of levels.

Accordingly, the following formula demonstrates the desired value of the row-level:

$$
y_{n-1}=\frac{y_{n}}{\bar{K}} \quad \text { or } y_{n}=\bar{K} \cdot y_{n-1} \text {. }
$$

\section{Characterization of indicators in terms of opportunities and threats using fuzzy logic.}

The membership function is determined for each indicator to characterize the degree of confidence regarding the readiness to introduce innovative banking technologies using the corresponding indicator. That is why it is necessary to break the interval between the minimum and maximum values of each indicator over the studied time into intervals corresponding to different confidence levels $-0 \%, 10 \%, \ldots, 100 \%$.

The next step is to classify the values of all indicators based on the estimation of their current level by the formula (Kozmenko and Roienko, 2013):

$$
\lambda_{i j}= \begin{cases}0, & x_{i} \notin A_{j} \\ 1, & x_{i} \in A_{j}\end{cases}
$$

where $i=2004,2005, \ldots, 2018$ - years;

$\mathrm{j}=1,2, \ldots, 11-$ serial number of the confidence level;

$\lambda_{i j}$ - binary value of the indicator;

$x_{i}$ - value of the indicator;

$A_{j}$ - the interval of values that corresponds to the $j$-level of confidence.

Then the sum of the binary values $\Lambda_{j}$ for every confidence level is calculated:

$$
\Lambda_{j}=\sum_{i=2004}^{2018} \lambda_{i j}
$$

The additive convolution method is used to determine the readiness for implementing innovations in banking: 


$$
Q=\frac{1}{N} \cdot \sum_{j=1}^{11} \Lambda_{j} \cdot R_{j}
$$

where $R_{j}$ - confidence level.

3. Determining the priority of the impact factors (indicators) on the readiness to implement banking innovations using the principal component method.

\section{Determination of weights of indicators.}

Using the obtained ranks, the Fishburn formula calculates the weights of the parameters:

$$
w_{i}=\frac{2 \cdot\left(N-r_{i}+1\right)}{N \cdot(N+1)}
$$

where $w_{i}$ - the weight of i-indicator;

$\mathrm{N}$ - total number of indicators;

$r_{i}-$ the rank of $\mathrm{i}$ - indicator.

\section{Bringing the input data array to a single comparable form.}

To bring all indicators to a single comparative form, the input predictors were normalized using the relative method (Boyko \& Roienko, 2014):

$$
n_{i j}=\frac{\left|x_{i j}\right|}{\max _{t} x_{i j}}
$$

where $x_{i j}$ - the value of $\mathrm{i}$ - indicator per $\mathrm{j}$-year;

$n_{i j}$ - the normalized value of i-predictor per $j$-year;

$i=1,2, \ldots, 12 ; j=2004,2005, \ldots, 2018$.

6. Calculation of a general indicator of the country's readiness to introduce innovative banking technologies.

Generalized Harrington function was used to provide a general description of the investment attractiveness of innovative banking customer service technologies:

$$
D=\sqrt[N]{\prod_{i=1}^{N} d_{i}}=\sqrt[N]{\prod_{i=1}^{N} \exp \left(-\exp \left(v_{i j}\right)\right)}=\sqrt[N]{\prod_{i=1}^{N} \exp \left(-\exp \left(\frac{n_{i j} \cdot Q_{i} \cdot w_{i}}{100}\right)\right)}
$$

where $d_{i j}=\exp \left(-\exp \left(-v_{i j}\right)\right)-$ partial desirability;

$v_{i j}=\frac{n_{i j} \cdot Q_{i} \cdot w_{i}}{100}$

$N=12-$ number of factors for evaluating the research object state. 
7. Making a forecast for the next four years regarding the readiness of countries to introduce innovations in the banking sector based on the Brown-Mayer exponential smoothing method.

The forecast determines the expected scenarios of the country's development in terms of introducing innovative banking technologies based on the hypothesis that the main factors and trends at the time of recent observations have a decisive impact on the forecasted period.

A necessary condition for constructing a non-linear Brown-Mayer model is the construction of a second-order parabola, which is described using the following mathematical equation:

$$
I P_{t}=p_{0}+p_{1} \cdot t+p_{2} \cdot t^{2}
$$

where $I P_{t}$ - the level of readiness of the country for the introduction of innovative banking technologies for the $\mathrm{t}$-th year;

$p_{0}, p_{1}, p_{2}$ - constants, parameters of the regression equation describing the dependence of the levels of the investigated time series on the time factor (year).

Having evaluated the parameters of the non-linear regression equation for the dependence of the effective attribute on the time factor, it is necessary to carry out a range of intermediate calculations to formalize the mathematical relationship, which will allow calculating forecast values in the context of the short term:

- calculation of initial conditions:

$$
\left\{\begin{array}{c}
U_{0}^{1}(I P)=p_{0}-\frac{1-\beta}{\beta} \cdot p_{1}+\frac{(1-\beta)(2-\beta)}{2 \beta^{2}} \cdot p_{2} \\
U_{0}^{2}(I P)=p_{0}-\frac{2(1-\beta)}{\beta} \cdot p_{1}+\frac{(1-\beta)(3-2 \beta)}{2 \beta^{2}} \cdot p_{2} \\
U_{0}^{3}(I P)=p-\frac{3(1-\beta)}{\beta} \cdot p_{1}+\frac{(1-\beta)(4-3 \beta)}{2 \beta^{2}} \cdot p_{2}
\end{array}\right.
$$

- calculation of exponential averages:

$$
\left\{\begin{array}{c}
U_{t}^{1}(I P)=\beta \cdot I P_{t}+(1-\beta) U_{0}^{1}(I P) \\
U_{t}^{2}(I P)=\beta \cdot U_{t}^{1}(I P)+(1-\beta) U_{0}^{2}(I P) \\
U_{t}^{3}(I P)=\beta \cdot U_{t}^{2}(I P)+(1-\beta) U_{0}^{3}(I P)
\end{array}\right.
$$

- calculation of the parameters of the forecast non-linear trend regression equation in the form of a second-order parabola:

$$
\left\{\begin{array}{c}
q_{0}=3 \cdot\left[U_{t}^{1}(I P)-U_{t}^{2}(I P)\right]+U_{t}^{3}(I P) \\
q_{1}=\frac{\beta}{(1-\beta)^{2}}\left[(6-5 \beta) U_{t}^{1}(I P)-2(5-4 \beta) U_{t}^{2}(I P)+(4-3 \beta) U_{t}^{3}(I P)\right] \\
q_{2}=\frac{\beta^{2}}{(1-\beta)^{2}}\left[U_{t}^{1}(I P)-2 \cdot U_{t}^{2}(I P)+U_{t}^{3}(I P)\right]
\end{array}\right.
$$

Using the parameters calculated by formulas (12), the adaptive predictive equation of the second polynomial is as follows:

$$
I P_{t}=q_{0}+q_{1} \cdot l+\frac{1}{2} q_{2} \cdot l^{2}
$$


where 1 - forecasting period

\section{EMPIRICAL RESULTS AND DISCUSSION}

The results of calculating the confidence level for selected indicators that directly and indirectly characterize the country's readiness to introduce innovations in the banking sector are presented in Table 1.

Table 1

Results of calculating the confidence level for selected indicators for European countries

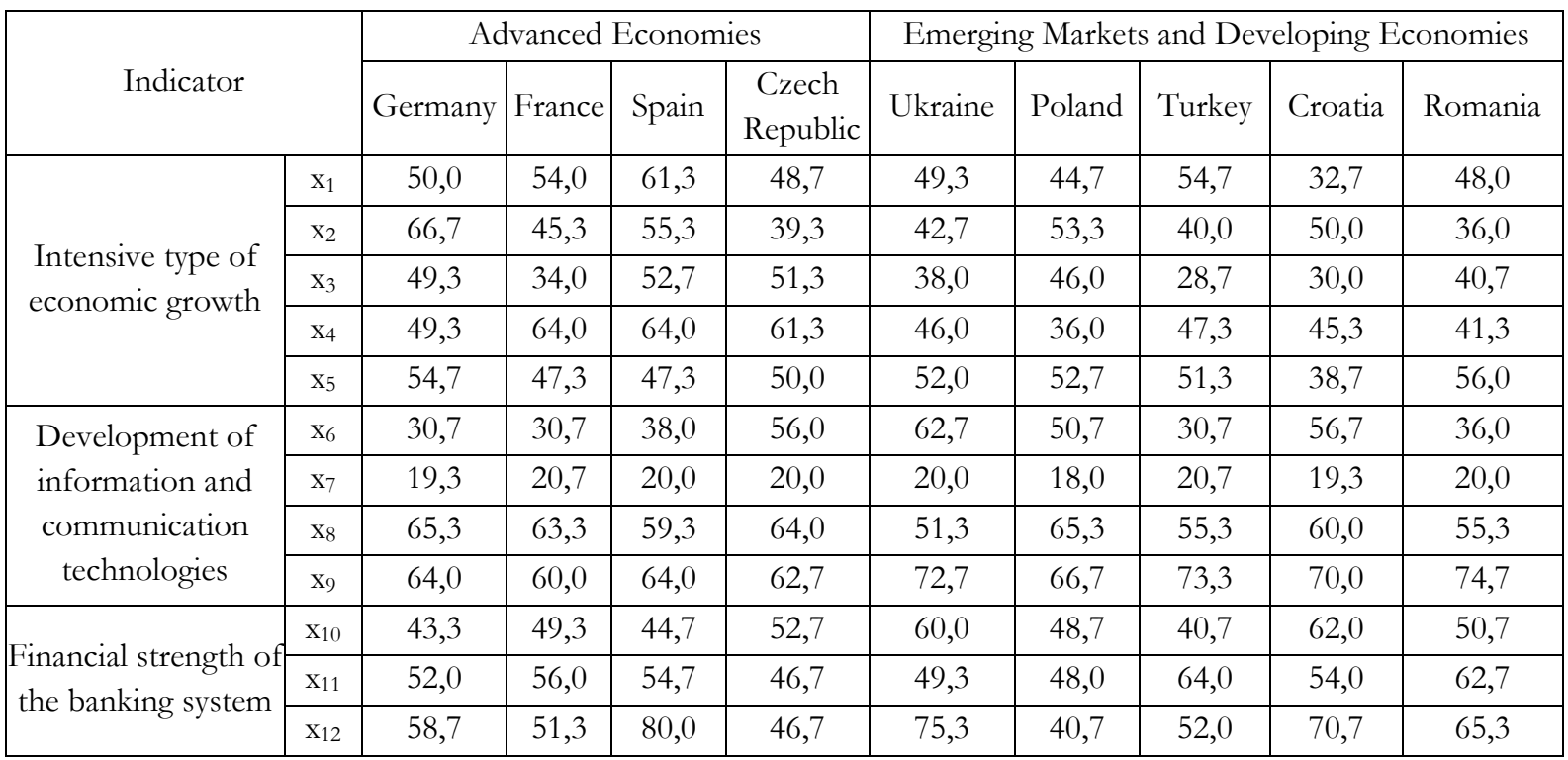

Source: developed by the authors based on World Bank, International Monetary Fund, Telecommunication Development Sector under the United Nations Development System.

As part of the factor analysis (principal component method), it is first necessary to calculate the factor loads using the Statistica 6.0 software. The eigenvalues of the correlation matrix are presented in Table 2.

Table 2

Eigenvalues of the correlation matrix

\begin{tabular}{|c|c|c|c|c|}
\hline \multirow{2}{*}{ Value number } & \multicolumn{2}{|c|}{ Eigenvalue of the correlation matrix and related statistics, active variables only } \\
\cline { 2 - 5 } & Eigenvalue & $\begin{array}{c}\text { Total } \\
\text { variance, } \%\end{array}$ & $\begin{array}{c}\text { Cumulative } \\
\text { eigenvalue }\end{array}$ & Cumulative, $\%$ \\
\hline 1 & 6,460157 & 53,83464 & 6,46016 & 53,8346 \\
\hline 2 & 2,151181 & 17,92651 & 8,61134 & 71,7612 \\
\hline 3 & 1,355515 & 11,29596 & 9,96685 & 83,0571 \\
\hline 4 & 0,743657 & 6,19714 & 10,71051 & 89,2543 \\
\hline 5 & 0,506028 & 4,21690 & 11,21654 & 93,4712 \\
\hline 6 & 0,399108 & 3,32590 & 11,61565 & 96,7971 \\
\hline 7 & 0,194760 & 1,62300 & 11,81041 & 98,4201 \\
\hline 8 & 0,106377 & 0,88647 & 11,91678 & 99,3065 \\
\hline 9 & 0,066849 & 0,55708 & 11,98363 & 99,8636 \\
\hline 10 & 0.011657 & 0,09714 & 11,99529 & 99,9607 \\
\hline 11 & 0,003850 & 0,03209 & 11,99914 & 99,9928 \\
\hline 12 & 0,000860 & 0,00717 & 12,00000 & 100,0000 \\
\hline
\end{tabular}

Source: developed by the authors. 
The factor corresponding to the maximum value (6.46) describes approximately $54 \%$ of the total variation. The second factor for the value (2.15) is responsible for about $18 \%$ of the total variation, etc. In this case, only the first two eigenvalues account for $71.8 \%$ of the total variation. Thus, it is sufficient to use two factors for further consideration.

The next step in terms of each indicator is the arithmetic mean of the factor load, weighted on the variance of the contribution of the corresponding factor in the effective feature. The obtained values provide the ranking of indicators from 1 to 12 .

Based on the results of factor analysis and using the formula (6) the indicator weights are calculated (table 3).

Table 3

The results of determining the weights for indicators that characterize the country's readiness to implement banking innovations by country

\begin{tabular}{|c|c|c|c|c|c|c|c|c|c|c|}
\hline \multirow{2}{*}{\multicolumn{2}{|c|}{ Indicator }} & \multicolumn{4}{|c|}{ Advanced Economies } & \multicolumn{5}{|c|}{ Emerging Markets and Developing Economies } \\
\hline & & \multirow{2}{*}{$\begin{array}{c}\text { Germany } \\
0,038\end{array}$} & \multirow{2}{*}{\begin{tabular}{|c|} 
France \\
0,103
\end{tabular}} & \multirow{2}{*}{$\begin{array}{l}\text { Spain } \\
0,077\end{array}$} & \multirow{2}{*}{$\begin{array}{c}\begin{array}{c}\text { Czech } \\
\text { Republic }\end{array} \\
0,051\end{array}$} & \multirow{2}{*}{$\begin{array}{c}\text { Ukraine } \\
0,051\end{array}$} & \multirow{2}{*}{\begin{tabular}{|r|} 
Poland \\
0,038
\end{tabular}} & \multirow{2}{*}{\begin{tabular}{|c|} 
Turkey \\
0,051
\end{tabular}} & \multirow{2}{*}{$\begin{array}{c}\text { Croatia } \\
0,064\end{array}$} & \multirow{2}{*}{$\begin{array}{c}\text { Romania } \\
0,154\end{array}$} \\
\hline \multirow{5}{*}{$\begin{array}{l}\text { Intensive type of } \\
\text { economic growth }\end{array}$} & $\mathrm{x} 1$ & & & & & & & & & \\
\hline & $\mathrm{x} 2$ & 0,141 & 0,128 & 0,154 & 0,128 & 0,141 & 0,154 & 0,154 & 0,154 & 0,038 \\
\hline & $\mathrm{x} 3$ & 0,115 & 0,141 & 0,064 & 0,090 & 0,103 & 0,141 & 0,128 & 0,038 & 0,128 \\
\hline & $\mathrm{x} 4$ & 0,026 & 0,013 & 0,103 & 0,064 & 0,013 & 0,051 & 0,026 & 0,051 & 0,141 \\
\hline & $\mathrm{x} 5$ & 0,090 & 0,026 & 0,026 & 0,013 & 0,026 & 0,013 & 0,038 & 0,026 & 0,026 \\
\hline \multirow{4}{*}{$\begin{array}{l}\text { Development of } \\
\text { information and } \\
\text { communication } \\
\text { technologies }\end{array}$} & $x 6$ & 0,103 & 0,090 & 0,038 & 0,115 & 0,154 & 0,115 & 0,077 & 0,115 & 0,115 \\
\hline & $\mathrm{x} 7$ & 0,154 & 0,115 & 0,128 & 0,103 & 0,090 & 0,128 & 0,115 & 0,128 & 0,064 \\
\hline & $\mathrm{x} 8$ & 0,013 & 0,038 & 0,013 & 0,026 & 0,038 & 0,064 & 0,013 & 0,013 & 0,013 \\
\hline & $\mathrm{x} 9$ & 0,128 & 0,051 & 0,090 & 0,154 & 0,077 & 0,077 & 0,090 & 0,077 & 0,077 \\
\hline \multirow{3}{*}{$\begin{array}{l}\text { Financial strength of } \\
\text { the banking system }\end{array}$} & $\mathrm{x} 10$ & 0,077 & 0,064 & 0,051 & 0,038 & 0,128 & 0,026 & 0,103 & 0,090 & 0,051 \\
\hline & x11 & 0,064 & 0,077 & 0,115 & 0,077 & 0,064 & 0,103 & 0,141 & 0,103 & 0,103 \\
\hline & $\mathrm{x} 12$ & 0,051 & 0,154 & 0,141 & 0,141 & 0,115 & 0,090 & 0,064 & 0,141 & 0,090 \\
\hline
\end{tabular}

Source: developed by the authors.

The data in Table 3 show that the priority of factors influencing the country's readiness to innovate in the banking sector varies depending on the country under study. The study revealed that the financial factor of the banking system is still the most significant factor for the majority of the countries under consideration (France, Spain, Ukraine, Turkey, Croatia). For another group of countries (Germany, Czech Republic, Poland), the development of information and communication technologies plays a systemically important role in enhancing the processes of introducing banking innovations. It is worth noting that the gap in the fluctuation of values within the studied groups of indicators is relatively insignificant and does not exceed 0.08 c.u. A significant role in stimulating innovation processes in the banking sector is played by foreign capital, which is typical for all countries under consideration. Thus, the hypothesis is erroneous regarding the same set of significant factors influencing the readiness to introduce banking innovations for advanced economies, emerging markets, and developing economies. The main determinants that cause the intensification of innovative processes in the banking sector are individual for each country. An empirical study showed the absence of patterns regarding impact factors for advanced economies, emerging markets, and developing economies. 
An integrated indicator is built on the basis of generalized Harrington function (formula 8). The results of the calculation of the integrated assessment of the readiness to introduce innovative banking technologies in countries, depending on their referral to advanced economies, emerging markets and developing economies (Fig. 2).

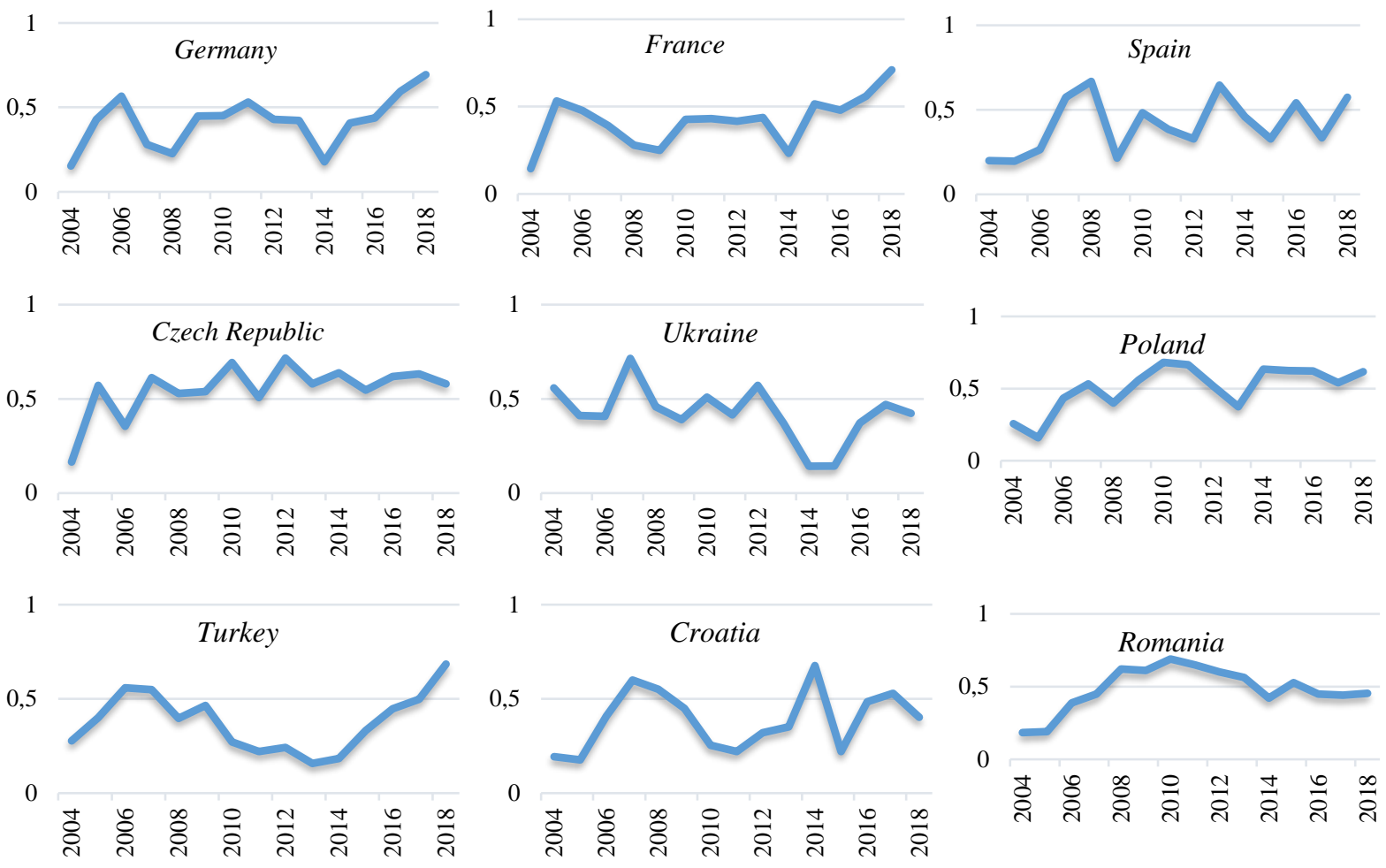

Figure 2. Dynamics of the readiness of European countries to introduce innovative banking technologies during 2004-2018

Source: Calculated by the authors

The results of assessing the readiness to introduce innovative banking technologies showed a gradual improvement of technological and economic conditions in countries necessary to intensify the innovation process in banking. In 2018, the highest level was observed in the following countries: France (0.710 c.u.), Germany (0.693 c.u.), Turkey (0.685 c.u.), Poland (0.616 c.u.). At the same time, the lowest capacity was observed for the following countries: Ukraine (0.423 c.u.), Croatia (0.402 c.u.), Romania (0.454 c.u.). In particular, in Ukraine, the main obstacles to the introduction of innovations by financial institutions are the low quality and level of Internet coverage, low level of financial literacy of the population, insufficient state funding for innovation projects and knowledge-intensive industries.

The final stage of the study is the prediction of the generalized characteristics of the readiness to introduce innovative banking technologies. Having performed the calculations using the formula (9-13), the authors obtained the Brown-Mayer forecast equation and the forecast of the country's readiness to implement innovative banking technologies (Table 4). 
Table 4

The results of forecasting the level of readiness to introduce innovative banking technologies by the country for 2019-2022

\begin{tabular}{|c|c|c|c|c|c|}
\hline Year & Formalization & 2019 & 2020 & 2021 & 2022 \\
\hline Germany & $I P_{t}^{G}=0.6043+0,0432 \cdot l+\frac{1}{2} 0,0123 \cdot l^{2}$ & 0,654 & 0,715 & 0,789 & 0,875 \\
\hline France & $I P_{t}^{F}=0.6166+0,0429 \cdot l+\frac{1}{2} 0,0112 \cdot l^{2}$ & 0,665 & 0,725 & 0,796 & 0,878 \\
\hline Spain & $I P_{t}^{S}=0.5439+0,0238 \cdot l+\frac{1}{2} 0,0048 \cdot l^{2}$ & 0,570 & 0,601 & 0,637 & 0,677 \\
\hline Czech Republic & $I P_{t}^{C R}=0.5931+0,0070 \cdot l-\frac{1}{2} 0,0011 \cdot l^{2}$ & 0,600 & 0,605 & 0,609 & 0,613 \\
\hline Ukraine & $I P_{t}^{U}=0.4189+0,0009 \cdot l+\frac{1}{2} 0,0038 \cdot l^{2}$ & 0,422 & 0,428 & 0,438 & 0,452 \\
\hline Poland & $I P_{t}^{P}=0.6121+0,0189 \cdot l+\frac{1}{2} 0,0022 \cdot l^{2}$ & 0,632 & 0,654 & 0,678 & 0,705 \\
\hline Turkey & $I P_{t}^{T}=0.5362+0,0169 \cdot l+\frac{1}{2} 0,0055 \cdot l^{2}$ & 0,556 & 0,581 & 0,612 & 0,648 \\
\hline Croatia & $I P_{t}^{C}=0.4052+0,0043 \cdot l-\frac{1}{2} 0,0001 \cdot l^{2}$ & 0,409 & 0,414 & 0,418 & 0,422 \\
\hline Romania & $I P_{t}^{R}=0.4841+0,0107 \cdot l-\frac{1}{2} 0,0005 \cdot l^{2}$ & 0,495 & 0,505 & 0,514 & 0,523 \\
\hline
\end{tabular}

Source: Calculated by authors

The data in Table 4 indicate an increase in the readiness of countries to implement innovative banking technologies over the next four years, provided that the trend of previous years is preserved. The quality of the constructed forecast models for all countries under consideration was estimated based on the error, indicating the calculated data's adequacy. For countries with a low level of readiness to introduce innovations in the banking sector (Croatia, Ukraine), it is advisable to take a set of measures to increase the level of digitalization, supporting the development of intellectual production. It can create conditions for introducing innovations and has a synergistic effect that extends to economic, social, technological, and infrastructural components of state development.

\section{CONCLUSION}

Until recently, the development of innovative products was associated exclusively with the work of marketing departments of banks. However, today, the development of innovation requires special knowledge from various management areas, as well as technological and intellectual support of innovation. Therefore, the model for assessing the readiness to implement innovative banking technologies has been developed using fuzzy logic, which considers the nature of economic relations in the country, the state of technical means, and the adequacy of financial resources of banks. The use of fuzzy logic tools as a method for assessing the country's readiness to implement innovative banking technologies made it possible to avoid the establishment of clear boundaries between, for example, its high and medium levels. The empirical study made it possible to identify weaknesses in the country's development in terms of introducing innovative banking technologies. Therefore, these results can be used to formulate a strategic plan to develop the country's banking system. 


\section{ACKNOWLEDGEMENT}

This research was funded by the grant from the Ministry of Education and Science of Ukraine (No. s/r 0121U100467, 0121U109559, 0120U100473).

\section{REFERENCES}

Adeyinka, Ad. J., Daniel, Ad. Ad., Adeniyi, D. J. (2019). An Assessment of the Relationship Between the Volume and Value of Ict Transactions in the Nigerian Deposit Money Banks: 2007-2017. Financial Markets, Institutions and Risks, 3(1), 30-42. http://doi.org/10.21272/fmir.3(1).30-42.2019.

Aldomy, R. F., Thim, C. K., Lan, N. T. P., \& Norhashim, M. B. (2020). Bank concentration and financial risk in Jordan. Montenegrin Journal of Economics, 16(3). https://doi.org/10.14254/1800-5845/2020.16-3.3

Alikariev, O.F.U., Poliakh, S. (2018). Index of protection of the interests of consumers of the financial services market. Business Ethics and Leadership, 2(1), 78-95. https://doi.org/10.21272/bel.2(1).78-95.2018

Afonasova, M. A., Panfilova, E. E., Galichkina, M. A., \& Ślusarczyk, B. (2019). Digitalization in economy and innovation: The effect on social and economic processes. Polish Journal of Management Studies. https://doi.org/10.17512/pjms.2019.19.2.02

Biegun, K., \& Karwowski, J. (2020). Macroeconomic imbalance procedure (MIP) scoreboard indicators and their predictive strength of "multidimensional crises." Equilibrium, 15(1). https://doi.org/10.24136/eq.2020.001

Bilan, Y., Pimonenko, T., \& Starchenko, L. (2020). Sustainable business models for innovation and success: Bibliometric analysis. E3S Web of Conferences, 159 doi:10.1051/e3sconf/202015904037

Benazzouz, N. M. (2019). Innovator's Dilemma: Review of the Main Responses to Disruptive Innovation. Journal of Intercultural Management, 11(1). https://doi.org/10.2478/joim-2019-0005

Bod'a, M., \& Zimkova, E. (2019). Spatial aspect in bank branch performance management. Engineering Economics, $30(2)$. https://doi.org/10.5755/j01.ee.30.2.19210

Boyko, A., \& Roienko, V. (2014). Risk assessment of using insurance companies in suspicious transactions. Economic Annals-XXI, 11-12.

Brychko, M., Polách, J., Kuzmenko, O., \& Olejarz, T. (2019). Trust cycle of the finance sector and its determinants: The case of Ukraine. Journal of International Studies. https://doi.org/10.14254/2071-8330.2019/12-4/20

Brychko, M., Bilan, Y., Lyeonov, S., \& Mentel, G. (2020). Trust crisis in the financial sector and macroeconomic stability: A structural equation modelling approach. Economic Research-Ekonomska Istrazivanja. ttps://doi.org/10.1080/1331677X.2020.1804970

Cicea, C. (2020). Performance in public management. A research agenda with bibliometric approach. Administratie $S i$ Management Public, 2020(35). https://doi.org/10.24818/amp/2020.35-07

Chigrin, O., \& Pimonenko, T. (2014). The ways of corporate sector firms financing for sustainability of performance. International Journal of Ecology and Development, 29(3), 1-13.

Correia, L., \& Martins, P. (2019). The European crisis: Analysis of the macroeconomic imbalances in the rescued euro area countries. Journal of International Studies, 12(2). https:/ / doi.org/10.14254/2071-8330.2019/12-2/2

Cwiklicki, M., \& Wojnarowska, M. (2020). Circular economy and industry 4.0: One-way or two-way relationships? Engineering Economics, 31(4). https://doi.org/10.5755/j01.ee.31.4.24565

Druhov, O., Druhova, V., \& Pakhnenko, O. (2019). The influence of financial innovations on EU countries banking systems development. Marketing and Management of Innovations. https://doi.org/10.21272/mmi.2019.3-13

Didenko, I., Kryvych, Y., \& Buriak, A. (2018). Evaluation of deposit market competition: basis for bank marketing improvement. Marketing and Management of Innovations, 2, 129-141. https://doi.org/10.21272/mmi.2018.2-11

Didenko, I., Paucz-Olszewska, J., Lyeonov, S., Ostrowska-Dankiewicz, A., \& Ciekanowski, Z. (2020). Social safety and behavioral aspects of populations financial inclusion: A multicountry analysis. Journal of International Studies, 13(2), 347-359. doi:10.14254/2071-8330.2020/13-2/23

Dovha, N., Boychenko, V. (2017). Can banking innovations lead to new financial crisis: case of Central and Eastern Europe. Financial Markets, Institutions and Risks, 1(2), 80-86. http://doi.org/10.21272/fmir.1(2).80-86.2017.

Faccia, A., Moşteanu, N. R., Cavaliere, L. P. L., Santis, G. (2020). The rise of online banks in Italy "WIDIBA Bank" Case Study. Financial Markets, Institutions and Risks, 4(2), 80-97. https:/ /doi.org/10.21272/fmir.4(2).80-97.2020. 
Frolov, D. P., \& Lavrentyeva, A. V. (2019). Regulatory policy for digital economy: Holistic institutional framework. Montenegrin Journal of Economics, 15(4). https://doi.org/10.14254/1800-5845/2019.15-4.3

Goncharenko, T., Lopa L. (2020). Balance Between Risk And Profit In The Context Of Strategic Management: The Case Of Ukrainian Banks. SocioEconomic Challenges, 4(1), 111-121. http://doi.org/10.21272/sec.4(1).111121.2020

Grybaite, V., \& Stankevičienè, J. (2018). An empirical analysis of factors affecting sharing economy growth. Oeconomia Copernicana. https://doi.org/10.24136/oc.2018.031

Ijaz, S., Hassan, A., Tarazi, A., \& Fraz, A. (2020). Linking bank competition, financial stability, and economic growth. Journal of Business Economics and Management, 21(1), 200-221. https://doi.org/10.3846/jbem.2020.11761

Hussain, H. I., Kamarudin, F., Anwar, N. A. M., Nassir, A. M., Sufian, F., \& Tan, K. M. (2020). Impact of country's governance dimensions on bank revenue efficiency: Overview on middle east, Southeast Asia, and South Asia countries. Transformations in Business and Economics, 19(1).

Karkowska, R., \& Kravchuk, I. (2019). Identification of global systemically important stock exchanges. Equilibrium. https://doi.org/10.24136/eq.2019.002

Karaoulanis, A. (2018). Strategic Transformation and Innovation towards Blue Ocean Creation in a Changing Corporate Reality. Business Ethics and Leadership, 2(2), 49-55. https://doi.org/10.21272/bel.2(2).49-55.2018

Kasim, M. M., Ramli, R., Baten, M. A., Jamil, J. M., \& Taleb, M. (2019). Efficiency of banks in malaysia: A super efficiency approach. Engineering Economics, 30(4). https://doi.org/10.5755/j01.ee.30.4.19291

Knezevic, D. (2018). Impact of blockchain technology platform in changing the financial sector and other industries. Montenegrin Journal of Economics. https:// doi.org/10.14254/1800-5845/2018.14-1.8

Korzeb, Z., \& Niedziółka, P. (2020). Resistance of commercial banks to the crisis caused by the COVID-19 pandemic: the case of Poland. Equilibrium, 15(2). https://doi.org/10.24136/eq.2020.010

Kozmenko, S., \& Vasyl'yeva, T. (2008). Specialized innovative investment banks in Ukraine. Banks and Bank Systems. https://doi.org/10.21511/bbs.3(1).2008.01

Kozmenko, O., \& Roienko, V. (2013). Evaluation and use of indicators of insurance companies' investment activities. Investment Management and Financial Innovations, 10(3). https://doi.org/10.21511/imfi.10(3).2013.01

Kuzmenko, O. V., \& Koibichuk, V. V. (2018). Econometric Modeling of the Influence of Relevant Indicators of Gender Policy on the Efficiency of a Banking System. Cybernetics and Systems Analysis. https://doi.org/10.1007/s10559-018-0070-8

Lăzăroiu, G., Kovacova, M., Kliestikova, J., Kubala, P., Valaskova, K., \& Dengov, V. V. (2018). Data governance and automated individual decision-making in the digital privacy general data protection regulation. Administratie Si Management Public. https://doi.org/10.24818/amp/2018.31-09

Leonov, S., Frolov, S., \& Plastun, V. (2014). Potential of institutional investors and stock market development as an alternative to households' savings allocation in banks. Economic Annals-XXI, 11-12, 65-68. http://soskin.info/userfiles/file/2014/11-12_2014/Leonov_Frolov_Plastun.pdf

Leonov, S., Yarovenko, H., Boiko, A., \& Dotsenko, T. (2019). Information system for monitoring banking transactions related to money laundering. CEUR Workshop Proceedings, 2422, 297-307.

Liu, C., Shi, H., Cai, Y., Shen, S., \& Lin, D. (2019). A new pricing approach for SME loans issued by commercial banks based on credit score mapping and Archimedean Copula simulation. Journal of Business Economics and Management, 20(4), 618-632. https://doi.org/10.3846/jbem.2019.9854

Lewandowska, A., \& Stopa, M. (2020). The impact of innovative professional qualifications on the sense of employment security: Evidence from poland. Economics and Sociology, 13(3). https://doi.org/10.14254/2071789X.2020/13-3/5

Naroș, M.-S. (2019). Foreign Direct Investment and Human Capital Formation. Journal of Intercultural Management, $11(2)$. https://doi.org/10.2478/joim-2019-0013

Nikic, V. (2018). Perception of user interests for the development of bitcoin, the new payment technology in the see countries. Transformations in Business and Economics, 18(3).

Mangani, K. S., Syaukat, Y., Arifin, B., \& Tambunan, M. (2019). The role of branchless banking in performance of households' micro and small enterprises: The evidence from Indonesia. Economics and Sociology, 12(3). https://doi.org/10.14254/2071-789X.2019/12-3/8 
Mikhaylova, A. A., Mikhaylov, A. S., Savchina, O. V., \& Plotnikova, A. P. (2019). Innovation landscape of the baltic region. Administratie Si Management Public, 33. https://doi.org/10.24818/amp/2019.33-10

Obidjon, G., Zakharkin, O., \& Zakharkina, L. (2017). Research of innovation activity influence on return of stocks in industrial enterprises. SocioEconomic Challenges, 1(2), 80-102. https://doi.org/10.21272/sec.1(2).80-102.2017

Petroye, O., Lyulyov, O., Lytvynchuk, I., Paida, Y., \& Pakhomov, V. (2020). Effects of information security and innovations on Country's image: Governance aspect. International Journal of Safety and Security Engineering, 10(4), 459-466. doi:10.18280/ijsse.100404

Przekota, G., Rembeza, J., Mentel, G., \& Szetela, B. (2019). The relationship between the stock market and the economy: Evidence from central and eastern. European Countries. Transformations in Business and Economics, 18, 397-415.

Prayitno, G., Ahari, M.I., \& Rukmi, W.I. (2021). Structural equation model with partial least square (SEM-PLS) of place dependence with land used change. Journal of International Studies, 14 (1), 153-171. doi:10.14254/2071$8330.2021 / 14-1 / 11$

Skvarciany, V., Jurevičienè, D., Iljins, J., \& Gaile-Sarkane, E. (2018). Factors influencing a bank's competitive ability: the case of Lithuania and Latvia. Oeconomia Copernicana. https://doi.org/10.24136/oc.2018.001

Székely, S., Csata, Z., Cioca, L. L., \& Benedek, A. (2020). Industrial marketing 4.0-upgrading the industrial costumers' path to the digital economy. Polish Journal of Management Studies, 22(2). https://doi.org/10.17512/pjms.2020.22.2.35

Vasilieva, T., Lieonov, S., Makarenko I., Sirkovska, N. (2017). Sustainability information disclosure as an instrument of marketing communication with stakeholders: markets, social and economic aspects. Marketing and Management of Innovations, (4), 350-357. https://doi.org/10.21272/mmi.2017.4-31.

Vasilyeva, T., Kuzmenko, O., Bozhenko, V., \& Kolotilina, O. (2019). Assessment of the dynamics of bifurcation transformations in the economy. CEUR Workshop Proceedings, 2422, $134-146$. https://doi.org/10.1051/shsconf/20196504006.

Vasylieva, T., Radchenko, O., \& Kryvych, Y. (2014). Effect from Bank's marketing communication instruments usage estimation. Economic Annals-XXI. 7-8 (1). 65-68. http://soskin.info/userfiles/file/2014/7-8_2014/78_1/Vasylieva\%20Radchenko\%20Kryvych.pdf

Wolnicki, M., \& Piasecki, R. (2019). The New Luddite Scare: The Impact of Artificial Intelligence on Labor, Capital and Business Competition between US and China. Journal of Intercultural Management, 11(2). https://doi.org/10.2478/joim-2019-0007

Yarovenko, H., Bilan, Y., Lyeonov, S., \& Mentel, G. (2021). Methodology for assessing the risk associated with information and knowledge loss management. Journal of Business Economics and Management, 22(2), 369-387. doi:10.3846/jbem.2021.13925

Zakutniaia, A., Hayriyan, A. (2017). Transparency as competitive advantage of innovation driven companies. Business Ethics and Leadership, 1(1), 46-54. Doi: 10.21272/bel.2017.1-06 